DOI 10.18551/rjoas.2019-01.12

\title{
DEVELOPMENT STRATEGY AND EVALUATION OF NUTMEG PLANT FITNESS IN SOUTH ACEH DISTRICT: A CASE STUDY OF TAPAKTUAN SUBDISTRICT
}

\author{
Syarmudi ${ }^{\star}$ \\ Postgraduate Program, Syiah Kuala University, Banda Aceh, Indonesia \\ Sofyan, Indra \\ Faculty of Agriculture, Syiah Kuala University, Banda Aceh, Indonesia \\ *E-mail: syarmudi485@gmail.com
}

\begin{abstract}
This study aims to determine the appropriate development strategy for the development of nutmeg farming and to determine the level of suitability of nutmeg plantations in Tapaktuan Subdistrict, South Aceh Regency. The first problem of processing and data analysis method consists of descriptive data analysis and strategy planning analysis with SWOT analysis, while the second problem analysis uses the results of observations in the field using a tactical system based on the Land Map Unit (LMU). The results showed that based on the SWOT analysis, the strategies carried out by farmers for nutmeg development were (1) improving product quality through improved maintenance and business planning and developing market access information, (2) Increasing nutmeg productivity through eradicating pests and plant diseases, and (3) Improving the quality of HR of nutmeg farmers and PPL officers. Whereas based on the analysis of land suitability, it was found that Tapak Tuan Subdistrict could still be developed nutmeg plants in several suitable locations according to the criteria of nutmeg plant growth.
\end{abstract}

\section{KEY WORDS}

Land suitability, agriculture, strategy, strengths weakness opportunity threats.

Nutmeg is a native plant of Indonesia, because this plant originates from Banda and Maluku. Nutmeg plants spread throughout Java, at the time of the Marcopollo trip to China which had passed the island of Java in 1271 to 1295 , the cultivation of nutmeg plants continued to spread to reach the island of Sumatra. The world knows Maluku from the results of nutmeg and cloves (Bustaman, 2007). Larasati (2008) states that the portion of nutmeg with high economic value is the part of nutmeg and mace (flower) which can be used as nutmeg oil. While nutmeg meat can be used to be processed into candied nutmeg, nutmeg pickles, nutmeg dodol, nutmeg jam and syrup and other processed snacks.

In Indonesia, Aceh Province is one of the centers producing nutmeg. Aceh Province was ranked first among the provinces of other nutmeg production centers with average production from 2012 to 2016 amounting to 7,959 tons. Then ranked second as the nutmeg production center, namely North Maluku province with an average production from 2012 to 2016 amounting to 6,128 tons. Other provinces have production averages below 5000 tons (Secretariat General of the Ministry of Agriculture, 2016).

The development of nutmeg plants in Aceh needs serious attention considering that Aceh Nutmeg will be developed as one of the leading commodities. South Aceh has nutmeg gardens of 30,000 hectares. However, 5,000 hectares of gardens have died in recent years due to pests. As a result the productivity of the average tree decreases. In 2002, the yield of nutmeg trees could still reach $30 \mathrm{~kg}$ per tree but the last harvest season in 2013 was only about $1 \mathrm{~kg}$ per tree (Forum Pala Aceh, 2012).

In order to increase the role of nutmeg commodities both domestically and internationally as well as to improve the welfare of farmers, appropriate efforts are needed, namely through the development of nutmeg plants in the centers of nutmeg development. Likewise with the nutmeg commodity in South Aceh Regency. This nutmeg is included in 
plantation crops which have the largest planting area in South Aceh Regency, which is 15,821 hectares. The most widely cultivated nutmeg is in Meukek District (3,785 hectares) and Tapaktuan District (2,177 hectares). In 2015, the production of nutmeg in South Aceh Regency reached 6,614 tons; Meukek sub-district produces 2,082 tons and Tapaktuan subdistrict produces 1,022 tons (BPS, 2016).

Soil analysis determines the level of suitability of the soil to agricultural activities and the types of plants planted, for example the level of suitability of nutmeg plants in Tapaktuan Sub-district, South Aceh Regency. Tapaktuan District is one of the sub-district in South Aceh which is a plantation area with nutmeg commodities. The information for land suitability classes in Tapaktuan sub-district is still very limited. Therefore evaluation for land suitability for plantation crops in this place needs to be done considering this place has extensive land and has the potential to develop plantation crops especially nutmeg plants. With information on land suitability classes for the development of plantation crops, it is expected that appropriate fratis management can be carried out to increase production and improve community welfare in Tapaktuan Subdistrict, South Aceh Regency.

\section{MATERIALS AND METHODS OF RESEARCH}

The location of the study was carried out in Tapak Tuan subdistrict, South Aceh Regency. The object of this research is nutmeg farming in Tapak Tuan District, South Aceh Regency. The scope of the research is about the strategy of developing and evaluating nutmeg land suitability in South Aceh District. The population in this study were nutmeg farmers in Tapak Tuan Subdistrict who had nutmeg planting area above 200 ha, so the selected villages were Gunung Kerambil Village, Batu Itam Village, Air Itam Village, and Panton Luas Village. Sampling from each village was $10 \%$ of the total number of farmers so that there were 53 samples of nutmeg farmers, 8 farmers in Gunung Kerambil Village, 11 farmers in Batu Itam Village, 17 farmers in Air Pinang Village, and 16 farmers in Panton Luas village.

Data collection is done using primary and secondary data. Primary data is obtained through surveys conducted by researchers to collect data by interviews using instruments in the form of questionnaires while secondary data is obtained through documents and literature. The variables observed were nutmeg farming, land suitability, strategy, and Strengths Weakness Opportunity Threats (SWOT).

\section{RESULTS AND DISCUSSION}

Characteristics of Respondents. Characteristics of respondents describe the identity of respondents divided into age, education level, family dependents, and farming experience. The description of the respondent characteristics was obtained from the results of distributing questionnaires to nutmeg farmers in the research location. Characteristics of respondents in the study location can be seen in Table 1 below.

Table 1 - Characteristics of Respondents in Research Sites

\begin{tabular}{ccc}
\hline No. & Characteristics of Respondents & Value \\
\hline 1 & Average Age (Year) & 49 \\
2 & Education (People) & 27 \\
& 1. Elementery School & 14 \\
& 2. Middle School & 7 \\
3 & 3. High School & 5 \\
4 & 4. Diploma/Bachelor & 5 \\
\hline
\end{tabular}

Source: Primary Data (2018).

Based on Table 1 shows that the age of farmers classified as productive age is 49 years old. At productive age, farmers can be more active and motivated to increase the 
quantity and quality of their farming quality. The education level of respondents in the location is still relatively low, from 53 farmers who were sampled 27 people with elementary education. Family dependents in the research location from the results obtained on average farmers have as many as 5 people, which mean that each farmer has the responsibility to provide 5 people from the business they run. Table 1 also shows that the average farming experience of farmers in the research location is 18 years.

Identification of Internal Factors. Based on the results of the identification of the internal environment, several strengths and weaknesses were found to influence the development of nutmeg plants. Identification of the internal environment was carried out with a questionnaire assistance tool and interviews were conducted with farmers who were sampled in 4 villages which were the research samples. The results of identification of the internal environment can be seen in table 2.

Table 2 - Factors of strengths and weaknesses possessed from identification of internal environment

\begin{tabular}{lll}
\hline No & Strengths & Weakness \\
\hline 1. & $\begin{array}{l}\text { Fertile soil conditions that support the growth of } \\
\text { nutmeg plants }\end{array}$ & $\begin{array}{l}\text { The Role of the Farmers Group Has Not Fully } \\
\text { Functioned }\end{array}$ \\
2. & $\begin{array}{l}\text { The Nutmeg Harvest Season that Continues to } \\
\text { Produce All Time }\end{array}$ & $\begin{array}{l}\text { Farmers Are Less Active in Receiving New } \\
\text { Information }\end{array}$ \\
3. $\quad \begin{array}{l}\text { Cultivation that is carried out on a gradual basis so } \\
\text { as to make farmers have a fairly long experience }\end{array}$ & $\begin{array}{l}\text { No Training Has Been Held to Prevent Disease } \\
\text { Attacks }\end{array}$ \\
4. $\quad \begin{array}{l}\text { Supporting and Experienced Workers in Cultivation } \\
\text { 5. Tapak Tuan District, South Aceh Regency One of the }\end{array}$ & Technology Used by Traditional Farmers \\
& Widest Areas of Pala Plants & \\
\hline
\end{tabular}

Source: Primary Data (2018).

Based on the data shows that the soil conditions in Tapaktuan Sub-district have a high fertility rate that is suitable for the growth of nutmeg plants, but has not been well treated and has not been optimally utilized. The fertile soil condition is one of the strength factors that also influences the prospect of developing nutmeg in Tapaktuan Sub-district, so it is given a rating rating of 4 , stating a very large strength. Nutmeg harvesting season in Tapaktuan Subdistrict has been fruiting at the age of 7-8 years, and is generally harvested every day by picking it using poles or left to fall to the ground and then taken. The nutmeg harvesting season that continues to bear fruit throughout the period is an important factor in the effort to develop nutmeg in Tapaktuan Sub-district, so it is given a rating value of 2 which states a moderate strength.

Nutmeg plants in Tapaktuan Sub-district have been developed for a long time, around 20 years, this is in accordance with the results of identification in the field which shows that on average the respondents have 18 years of farming experience. This condition illustrates that nutmeg farming is very prospective to be developed in Tapaktuan Sub-district in an effort to increase people's income so that it is given a rating rating of 3 which states great strength. Experienced workers are a force for the development of nutmeg plantations in Tapaktuan Sub-district and are given a rating value of 2 which states moderate strength. The location of the study shows that the Pala plants in Tapaktuan Sub-district as one of the largest regions producing nutmeg are a force for the development of nutmeg plantation business so they are given a rating rating of 1 which states a small strength.

Based on the results of the data at the study site, information was obtained that the nutmeg farmer groups formed in Tapaktuan Sub-district did not yet have a significant role in the development of nutmeg agribusiness, because they were still limited to formation groups that were not well organized. The role of farmer groups that have not fully functioned can influence the success of the business of developing nutmeg plants in Tapaktuan Sub-district so that they are given a rating of 4 which states that weaknesses are less significant.

Based on the results of the data show that nutmeg farmers in Tapaktuan Sub-district did not have access to information regarding both cultivation and processing technology and to the development of nutmeg commodity sales prices so that it was influential in nutmeg plantation business. There has been no training conducted by PPL for the prevention of pala 
plants and major diseases that affect the productivity of nutmeg plants which can directly reduce farmers' income, so they are given a rating of 3 which states significant weaknesses. The application of this still traditional technology to the business of developing nutmeg plants will reduce the productivity and income of nutmeg farmers, so that they are given a rating rating of 1 that expresses significant weaknesses. Processing of nutmeg yields that have not been optimal by farmers is a factor that influences the business of developing nutmeg plants, so it is given a rating value of 1 which states a very significant weakness.

Identification of External Factors. Identification of the external environment was obtained from the results of discussions carried out on elements from the South Aceh Agriculture Service and the Agricultural Extension Agency in Tapaktuan District. The results of identification of the External environment can be seen in table 3 .

Table 3 - Factors of opportunities and threats possessed from identification of the external environment

\begin{tabular}{|c|c|c|}
\hline No & Strengths & Weakness \\
\hline 1. & Increased Demand for High Customer Markets & $\begin{array}{l}\text { Number of Competitors Producing Nutmeg in Other } \\
\text { Regions }\end{array}$ \\
\hline 2. & Climate and Weather Factors That Support & The existence of pest attacking nutmeg \\
\hline 3. & Promising nutmeg prospects & Decrease in production \\
\hline 4. & $\begin{array}{l}\text { Nutmeg Can Be Processed Into Various Agro- } \\
\text { Industry }\end{array}$ & $\begin{array}{l}\text { There Is No Government Support Regarding Nutmeg } \\
\text { Products Processing Technology }\end{array}$ \\
\hline 5. & Nutmeg seeds are quite available & $\begin{array}{l}\text { Not yet optimal counseling about processing nutmeg } \\
\text { products }\end{array}$ \\
\hline
\end{tabular}

Source: Primary Data (2018).

Based on the data shows that the increase in high customer market demand is one of the opportunities that affect the development of nutmeg farming, so it is given a rating rating of 4 which states a very large opportunity. Results Data at the study site obtained information that the climate and weather in Tapaktuan Sub-district were very suitable for the growth of nutmeg plants, so they were given a rating of 4 which stated a very large opportunity.

Based on the data, the price of one kilogram of nutmeg (approximately 20) costs Rp. 3,700 , dried young nutmeg Rp. $38,000 \mathrm{~kg}^{-1}$, The promising prospect of nutmeg is one of the factors that can influence the development of nutmeg in Tapaktuan District, South Aceh Regency, so that it is given rating value 3 which states a great opportunity. Nutmeg can be processed into various types of agro-industry products, which is one of the factors that can influence the development of nutmeg farming in Tapaktuan Sub-district, so that it is given a rating of 3 which states a great opportunity. The results of the data show that the parent trees that will be used as a source of nutmeg seedlings in Tapaktuan Sub-district are quite available, so they do not become an obstacle in developing the nutmeg commodity, and are given a rating rating of 3 which states a great opportunity.

The number of competitors that produce nutmeg in other regions is one of the threat factors that can affect the development of nutmeg in Tapaktuan Sub-district, so it is given a rating of 4 which states a less significant threat. The presence of pests and nutmeg disease resulting in losses at the level of farmers in Tapaktuan Sub-district is one of the factors that can affect the development of nutmeg plantations, so this condition is given a rating rating of 3 which states a significant threat.

Nutmeg can decrease production due to pest and plant disease attacks because of lack of knowledge and skills of farmers in cultivating nutmeg plants and can affect the productivity of nutmeg plants, so it is a threat factor in the development of nutmeg plantations in Tapaktuan District, this condition is rated 2 which states a significant threat. The absence of government support regarding the technology of processing nutmeg products is an obstacle in the business of developing nutmeg commodities especially in Tapaktuan Subdistrict, so that it is a threat factor to the development of nutmeg plantations, this condition is given a rating rating of 1 which is a very significant threat. Not yet optimal counseling about processing nutmeg products is one of the factors that can influence the development of 
nutmeg plantations in Tapaktuan Sub-district, so that it is a threat, so it is given a rating value of 2 which states a significant threat.

IFE (Internal Factor Evaluation) Matrix Analysis. The factors analyzed are the key internal factors for developing nutmeg plants. These strategy factors are factors that become strengths and weaknesses which consist of weight values and scores. Score as in table 4 below:

Table 4 - Results of the IFAS SWOT Analysis of Nutmeg Development in Tapak Tuan District

\begin{tabular}{lccc}
\hline Internal factors & Weight & Rating & Score \\
\hline Strenght & 0,14 & 4 & 0,57 \\
The fertile soil condition of Berlin supports the growth of nutmeg & 0,09 & 2 & 0,17 \\
Harvest season that always bears fruit of all time & 0,11 & 3 & 0,34 \\
Cultivation that is carried out on a gradual basis so as to make farmers have a fairly & 0,06 & 2 & 0,17 \\
long experiance & 0,06 & 1 & 0,06 \\
Workers who support and are experienced in nutmeg cultivation & 0.49 & 12 & 1.31 \\
Tapak Tuan District is one of the largest regions producing nutmeg & 0.14 & 4 & 0.57 \\
\hline SUB TOTAL & 0.14 & 4 & 0.57 \\
Weakness & 0.11 & 3 & 0.34 \\
The Role of the Farmers Group Has Not Fully Functioned & 0.06 & 1 & 0.06 \\
Farmers are less active in receiving new information & 0.06 & 1 & 0.06 \\
No Training Has Been Held to Prevent Disease Attacks & 0.51 & 13 & 1.6 \\
The technology used by farmers is still traditional & & 2.91 \\
Processing of nutmeg yields that have not been optimal & & 2 \\
\hline SUB TOTAL & & & \\
\hline Total &
\end{tabular}

Source: Primary Data (2018).

According to the results of calculations in Table 4, the overall total score of the internal factors of nutmeg crop farmers that respond to strengths and weaknesses is 2.91. This shows that nutmeg planters are able to use strength to reduce their weaknesses with a subtotal strength score of 1.31 and a subtotal weakness score of 1.6.

EFE Matrix Analysis (External Factor Evaluation). External factor analysis defines opportunity factors that can be exploited and threat factors that must be faced by nutmeg farmers. External key factors which consist of weight values and ratings and scores as in table 5 below:

Table 5 - Results of SWOT Analysis of EFAS Matrix on Nutmeg Development in Tapak Tuan District

\begin{tabular}{llcc}
\hline Internal Factors & Weight & Rating & Score \\
\hline Opportunities & 0.13 & 4 & 0.51 \\
Increased customer market demand is high & 0.13 & 4 & 0.51 \\
Climate and weather factors that support & 0.10 & 3 & 0.31 \\
Promising nutmeg prospects & 0.10 & 3 & 0.31 \\
Nutmeg can be processed into various types of agro-industries & 0.06 & 3 & 0.31 \\
Nutmeg seeds are quite available & 0,56 & 17 & 3,64 \\
\hline SUB TOTAL & 0.13 & 4 & 0.51 \\
Threats & 0.10 & 3 & 0.31 \\
Many competitors produce nutmeg in other regions & 0.08 & 2 & 0.15 \\
The presence of pests and diseases that attack nutmeg & 0.05 & 1 & 0.05 \\
Decrease in production. & 0.08 & 2 \\
The absence of government support regarding the technology of processing nutmeg & 0.15 \\
products & 0,44 & 12 & 1,18 \\
Unoptimal counseling about processing nutmeg results & & 4.82 \\
\hline SUB TOTAL & & \\
\hline Total & & & 4 \\
\hline
\end{tabular}

Source: Primary Data (2018)

According to the results of calculations in Table 5 the overall total score scores of external factors from data processing respond to Opportunities and Threats of 4.82. This 
shows that nutmeg planters are able to take advantage of opportunities to face threats with a subtotal strength score of 3.64 and a subtotal threat score of 4.82 .

Formulation of Nutmeg Development Strategy in Tapaktuan District, South Aceh Regency IFAS Matrix. The IFAS value obtained is 1.31, which means that nutmeg plantations in Tapaktuan District have a strong internal position because they are able to use existing power to reduce their weaknesses. The highest weighting factor and the highest ranking is a factor that greatly affects nutmeg plantations in Tapaktuan District. The IFAS and EFAS matrices from the results of the SWOT analysis can be seen in Table 6 below:

Table 6. Matriks IFAS and EFAS

\begin{tabular}{cccc}
\hline \multirow{2}{*}{ EFAS } & IFAS & Strengths (S) & Weaknesses (W) \\
\hline \multirow{2}{*}{ Opportunities (O) } & Strategy (SO) $1,31+3,64=4,96$ & Strategy (WO) $1,60+3,64=5,24$ \\
& Threats (T) & Strategy (ST) $1,31+1,18=2,49$ & Strategy (WT) $1,60+1,18=2,78$ \\
\hline
\end{tabular}

Source: Primary Data (2018).

Based on the IFAS and EFAS matrix in table 6 above, the WO strategy of 5.24 is located in the third quadrant, meaning that the main strategy that must be applied by Tapaktuan Sub-district to develop nutmeg plantations is a turn around strategy, which seeks to minimize weaknesses to take advantage of the opportunities that exist. This strategy improves or overcomes internal weaknesses to take advantage of external opportunities. The WO strategies generated are:

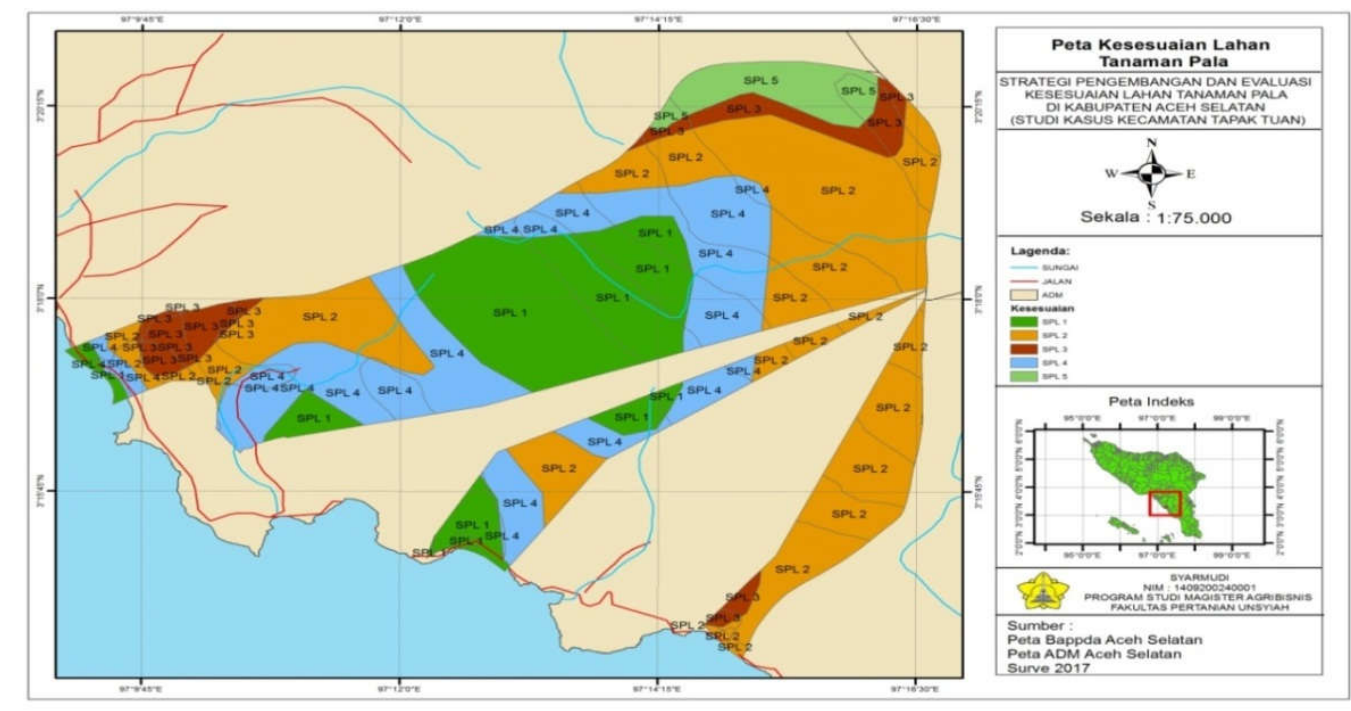

Figure 1 - Nutrient land suitability map at the research location

Participating in training held by the government regarding the processing of nutmeg products. The government can make training in nutmeg processing in the form of agroindustry so that it can add value to nutmeg products. Conduct training in business management and business finance and technical guidance on the application of nutmeg processing technology.

The results obtained in the IFAS matrix show that the weakness factor is very prominent $(54.90 \%)$ while the strength factor is less prominent $(45.10)$. The EFAS matrix which is very prominent is the opportunity factor $(75.53 \%)$ while the threat factor is less prominent $(24.47 \%)$.

Land Suitability Analysis. A land map unit based on the results of research in the field. The land map unit that has been created in the form of nutmeg land suitability map can be seen in Figure 1 below. 
The results of research on nutmeg suitability in the four villages sampled were Gunung Kerambil Village, Panton Luas, Batu Itam, and Air Pinang Village divided into 4 land suitability classes namely SPL I, SPL II, SPL III, and SPL IV. Land characteristics used to measure land suitability classes in the 4 classes are temperature (daily average temperature), water availability (rainfall, air humidity, and dry period), as well as erosion hazard (slope, and erosion hazard). The class of nutmeg compatibility in Tapaktuan Subdistrict divided in SPL I was in the Village of Mount Kerambil I, Mount Kerambil II, Mount Kerambil III, Batu Itam I, Batu Itam II, Batu Itam III, Batu Itam IV, Batu Itam V, Batu Itam, Extensive Pantan I, and Extensive Pantan II. In all the villages above have the same Land Use / Land Characteristics Requirements with an average temperature of $27.1 \circ \mathrm{C}$ (S1), rainfall ie $3250 \mathrm{~mm}$ (S3), air humidity 60-95\% (S1), Duration of Dry Period <2 month (S1), slope $<8 \%$ (S1) and low erosion hazard (S1) so that it can be concluded from the above data for the land suitability class on SPL 1 that there is a heavy limiting factor on water availability with rainfall of $3250 \mathrm{~mm}$.

The class of nutmeg conformity in Tapaktuan Subdistrict divided into SPL II was in the Village of Mount Kerambi I, Mount Kerambil II, Mount Kerambil III, Mount Kerambil IV, Mount Kerambil V, Mount Kerambil VI, Mount Kerambil VII, Gunung Kerambil VIII, Gunung Kerambil IX , Mount Kerambil X, Mount Kerambil, XI, Mount Kerambil XII, Gunung Kerambil XIII, Mount XIV, Mount Kerambil XV, Batu Itam I, Batu Itam II, Batu Itam III, Batu Itam IV, Extensive Pantan I, Extensive Pantan II, Pantan Extent III, Pantan Area IV, Pantan Area V, Pantan Area VI, Pantan Area VII, Pantan Area VII, Pantan Extent VIII, Extensive Pantan IX, Pantan X, Water Pinang I, Water Pinang I, Air Pinang II, Air Pinang III, Air Pinang III IV, Areca Palm V, Areca Palm, Areca Palm VII, Areca Palm VIII, Areca Palm IX, Areca Palm X, Areca Nut XI, Areca Nut XII, and Areca Nut XIII. In all the villages above have the same Land Use / Land Characteristics Requirements with an average temperature of $27.1 \circ \mathrm{C}$ (S1), rainfall ie $3250 \mathrm{~mm}$ (S3), air humidity 60-95\% (S1), Duration of Dry Period <2 month (S1), slope $16-25 \%$ (S3) and severe erosion hazard (S3) so that it can be concluded from the above data for the land suitability class on SPL II is S3wa, eh there is a heavy limiting factor on water availability with rainfall of $3250 \mathrm{~mm}$ and erosion hazards seen on\% slopes and erosion hazards. Whereas for slopes and erosion hazards can be improved by conservation techniques of making terraces with bench terraces (Hidayat, 2006).

The class of nutmeg conformity in Tapaktuan Subdistrict divided into SPL III is in Gunung Kerambil I Village, Kerambil II Mountain, Kerambil III Mountain, Kerambil IV Mountain, Kerambil V Mountain, Kerambil VI Mountain, VII Kerambil Mountain, Kerambil VIII, Air Pinang I, Pinang II, Pinang III, Extent I, Extent II, Extent III, Extent of Extent IV, Extent of Extent V, and Extensive Pantan VI. In all the villages above have the same Land Use / Land Characteristics Requirements with an average temperature of $27.1 \circ \mathrm{C}$ (S1), rainfall ie 3250 $\mathrm{mm}$ (S3), air humidity $60-95 \%$ (S1), Duration of Dry Period <2 month (S1), slope $26-40 \%$ (S3) and severe erosion hazard (S3) so that it can be concluded from the above data for the land suitability class on SPL III is S3wa, eh there is a heavy limiting factor on water availability with rainfall of $3250 \mathrm{~mm}$ and erosion hazards seen on\% slopes and erosion hazards.

The class of nutmeg suitability in Tapaktuan Subdistrict is divided into SPL IV in the Village of Pantan Luas I and Pantan Luas II. In all the villages above have the same Land Use / Land Characteristics Requirements with an average temperature of $27.1 \circ \mathrm{C}$ (S1), rainfall ie $3250 \mathrm{~mm}$ (S3), air humidity 60-95\% (S1), Duration of Dry Period <2 month (S1), slope $>40 \%(\mathrm{~N})$ and severe erosion hazard $(\mathrm{N})$ so that it can be concluded from the data above for land suitability classes in SPL IV that $N$ is a heavy limiting factor on water availability with rainfall of $3250 \mathrm{~mm}$ and erosion hazard which is seen on\% slopes and the erosion hazard is very heavy.

\section{CONCLUSION}

Based on the SWOT analysis of strategies carried out by farmers for nutmeg development namely (1) improving product quality through improved maintenance and 
business planning management and developing market access information, (2) Increasing nutmeg productivity through eradicating plant pests and diseases, and (3) Increasing the quality of HR of nutmeg farmers and PPL officers.

Based on the analysis of land suitability, it was found that the land suitability class SPL I, SPL II, SPL III was S3wa, uh meaning that development could still be carried out in the regions included in the SPL I, II, and III classes in addition to making horseshoe terraces. Whereas the SPL IV land suitability class is $\mathrm{N}$ which means it is not feasible to develop nutmeg on the land.

\section{REFERENCES}

1. Badan Pusat Statistik. (2016). South Aceh in figures 2016. South Aceh. BPS South Aceh.

2. Bustaman, S. (2007). Prospects and strategies for developing nutmeg in Maluku. Center for Assessment and Development of Agricultural Technology. Bogor.

3. Forum Pala Aceh. (2012). Report on the Area of Nutmeg Plant in South Aceh Regency. South Aceh.

4. Hidayat, M. Y. 2006. Evaluation of land suitability for sengon plants (Paraserianthes falcataria (L) Nielsen) in several slope class units. Skripsi. Bogor Agricultural Institute, Bogor.

5. Larasati, Nadia P, Ariani D, Dewi P, Tantri N, Arief N dan AS Gangga. (2008). Development of Nutmeg Farming and Efforts to Increase Value Added Products through Marketing with the Establishment of Business Groups. Final Report of the Student Creativity Program. Bogor Agricultural Institute. Bogor.

6. Secretariat General of the Ministry of Agriculture. (2016). Outlook Pala. Center for Agricultural Data and Information Systems. Jakarta. 